\title{
Effect of Insulin on Growth of Cultured Human Arterial Smooth Muscle Cells
}

\author{
B. Pfeifle and H. Ditschuneit \\ Department of Internal Medicine, University of Ulm, UIm, FRG
}

Summary. The effect of insulin (10-10000 mU/1) on the proliferation of cultured human arterial smooth muscle cells was studied. Smooth muscle cells were cultivated by explantation. Cells from the third to the fifth subculture were used. Proliferation was studied by growth curve experiments. Insulin stimulated cell proliferation in all concentrations $(p<0.001)$. Growth was however stimulated more by a medium containing $10 \%$ fetal calf serum. The highest concentration of insulin produced only $35 \%$ of the effect of $10 \%$ fetal calf serum. Our results support the hypothesis that insulin may play a role in atherosclerosis.

Key words: Insulin, smooth muscle cells, atherosclerosis

Diabetes is a major risk factor for atherosclerosis. The changes in the vessel wall begin earlier and advance more rapidly in diabetic patients than in nondiabetics [1]. Smooth muscle cells play an important role in development of atherosclerosis [2,3]. According to the hypothesis described by Ross [2], atherosclerosis begins with an injury of the endothelium. At these sites of injury various factors such as lipoproteins, hormones and platelet-derived factors infiltrate the subendothelial tissue. The infiltration of these factors may lead to the proliferation of smooth muscle cells derived from the intima and media.

To study whether insulin is one of the serum factors which lead to the proliferation of smooth muscle cells, the effect of insulin on the growth of cultured animal arterial smooth muscle cells was investigated $[4,5]$. A hypothesis that insulin may contribute to the development of atherosclerosis was established by
Stout [6]. In this study we have investigated the growth-promoting effect of insulin on cultured human arterial smooth muscle cells.

\section{Material and Methods}

Smooth muscle cells were cultivated from segments of human arteries, which were obtained from operations on men aged 40 to 60 years.

For these experiments four segments of arteries from three subjects were used. Three segments of arteries were obtained by aneurysmectomy from two subjects aged 48 and 56 years. The segments used were of normal structure. One segment of artery was obtained by aorto-aortic bypass from a subject aged 35 years. This arterial wall was of normal structure apart from a thickend adventitia. No subject was taking drugs known to affect metabolism. Informed consent was obtained from the patients.

\section{Cell Culture Technique}

The intima and inner media of a segment of artery were stripped under sterile conditions. The stripped tissue was put into dessecting medium and was cut with a scalpel into small pieces $1 \mathrm{~mm}^{2}$. The dessecting medium used was Dulbecco's Modified Eagle Medium (Gibco, Karlsruhe) containing $10 \mathrm{ml} / 1$ Tris buffer $(2 \mathrm{~mol} /$ l, ph 7.4). These pieces were transferred to a $25 \mathrm{ml}$ Falcon flask. One flask contained 15-20 pieces. The medium was removed and replaced by a tissue culture medium containing $100 \mathrm{ml} / \mathrm{l}$ fetal calf serum. The culture medium used was Dulbecco's Modified Eagle Medium containing $10 \mathrm{ml} / 1$ MEM NEAA-solution (Gibco, Karlsruhe) and $30 \mathrm{ml} / 175 \mathrm{~g} / 1$ sodium bicarbonate. The concentration of insulin in the fetal calf serum was $5 \mathrm{mU} / 1$.

Smooth muscle cells were grown out in about three weeks. From this primary culture subcultures were made by trypsinisation. The concentration of trypsin used was $0.5 \mathrm{~g} / \mathrm{l}$.

\section{Growth Curve Experiments}

The proliferation of smooth muscle cells in the logarithmic growth phase and in the stationary growth phase was examined.

To examine the proliferation of smooth muscle cells during logarithmic growth, $4 \mathrm{ml}$ of a cell suspension with $10^{5}$ cells $/ \mathrm{ml}$ in culture medium containing $10 \mathrm{ml} / 1$ fetal calf serum was pipetted 


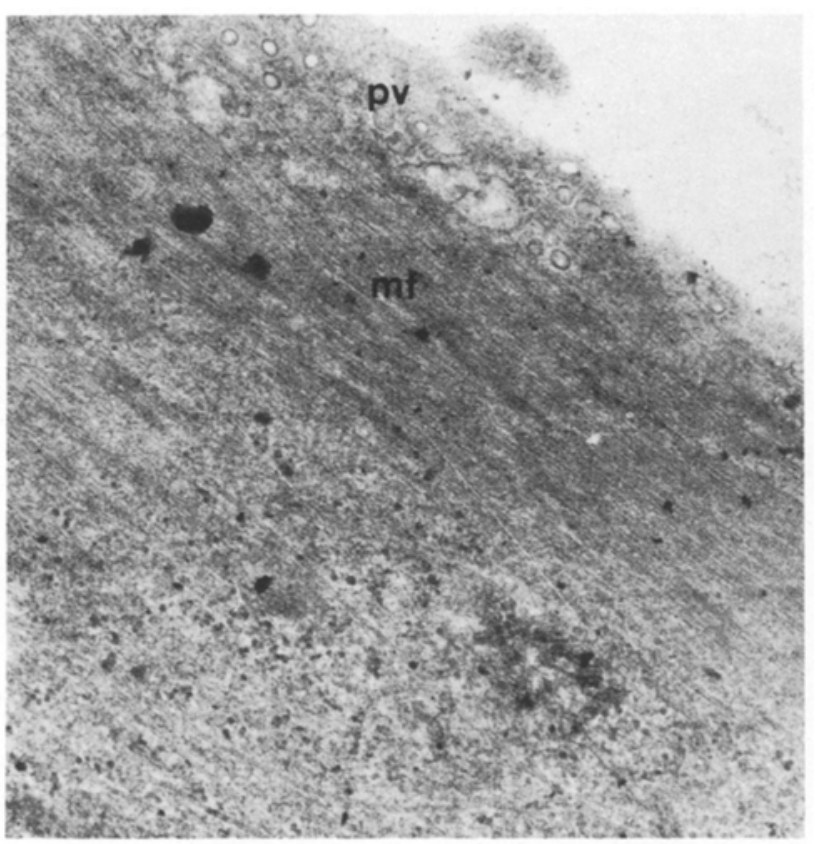

Fig. 1. Cultivated human smooth muscle cell from the 4th passage. The cell contains myofilaments (mf) which are predominantly located at the periphery of the cell. Along the cell membrane many pinocytotic vesicles (pv) are present

into Falcon tissue culture flasks on day 0. On day 2 the tissue culture medium was removed and the test medium containing $10 \mathrm{ml} / 1$ fetal calf serum and insulin (porcine insulin, Hoechst, Frankfurt) at a concentration of $10-10000 \mathrm{mU} / 1$ were added. The test medium was replaced by fresh medium every third day. Control groups of cells continued their growth in medium containing only 10 and $100 \mathrm{ml} / 1$ fetal calf serum. On day $2,4,6,8,10,12$ and 13 the cells were counted twice in a Fuchs-Rosenthal counting chamber.

To study the proliferation of cells taken from the stationary growth phase in $10 \mathrm{ml} / \mathrm{l}$ serum medium, a cell suspension with $10^{5}$ cells $/ \mathrm{ml}$ tissue culture medium containing $1 \%$ fetal calf serum was seeded into Falcon flasks. After 9 days when cells had reached the stationary growth phase the test medium was added with an insulin concentration of $10-10000 \mathrm{mU} / \mathrm{l}$. This is referred to as day 0 . The test medium was replaced by fresh medium every third day. Control groups of cells were grown in $10 \mathrm{ml} / 1$ medium and $100 \mathrm{ml} / 1$ medium as described above. Cell counting was carried out on day $0,2,4,6,8$ and 10. For these experiments cells from the third passage were used.

\section{Electron Microscopy}

To study the morphological character of the cultured smooth muscle cells by electron microscopy, the cells were grown in Falcon tissue culture flasks as described. The cell layer was rinsed with $0.1 \mathrm{~mol} / 1$ sodium phosphate buffer containing $20 \mathrm{~g} / 1$ saccharose,

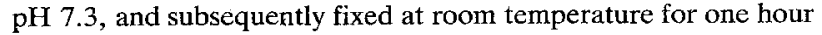
with $20 \mathrm{~g} / 1$ glutaraldehyde, $10 \mathrm{~g} / 1$ tannin and $20 \mathrm{~g} / 1$ saccharose in $0.1 \mathrm{~mol} / \mathrm{l}$ sodium phosphate buffer $\mathrm{pH}$ 7.3. After fixation the cell layer was rinsed again with $0.1 \mathrm{~mol} / 1$ sodium phosphate buffer and postfixed with $20 \mathrm{~g} / 1 \mathrm{OsO}_{4}$ in $0.1 \mathrm{~mol} / 1$ sodium phosphate buffer pH 7.3 for $2 \mathrm{~h}$. Finally cells were dehydrated through a graded series of ethanol solutions, contrasted with a saturated solution of uranyl-acetate, and embedded in EPON. After the plastic was hardened overnight, the flask was broken and the plastic layer covering the cell layer was removed. Blocks were sectioned with an ultramicrotome. The sections were stained with lead citrate and viewed with a Philips E 302 electron microscope.

\section{Statistical Analysis}

For statistical analysis the means of the total number of cells of twofold determinations in each of duplicate plates were used. Results were then treated by analysis of variance, and significance assessed using the $F$-test.

\section{Results}

Human smooth muscle cells from the intima and inner media of a segment of artery grew out from the explants after three weeks. They grew in multiple overlapping layers, characteristic for the growth pattern of smooth muscle cells.

Cells from the third to the fifth passage were used. The ultrastructure of the cultured smooth muscle cells did not change during these passages. Smooth muscle cells which advanced in culture showed alternations in their morphology. These cells contained many myofilament bundles and pinocytotic vesicles were grouped along the cell membrane (Fig. 1). The cells also contained large mitochondria, free ribosomes, a well-developed rough endoplasmatic reticulum, Golgi-apparatus and large dense bodies.

The effect of insulin $(10-10000 \mathrm{mU} / 1$ plus $10 \mathrm{ml} / 1$ fetal calf serum on the proliferation of smooth muscle cells during the logarithmic growth phase is shown in Figure 2. The results show that cells which were grown in medium containing insulin multiplied more rapidly and reached the stationary growth phase earlier than cells which were grown in medium containing only $100 \mathrm{ml} / \mathrm{l}$ fetal calf serum. Cells which were grown in medium containing $100 \mathrm{ml} / 1$ fetal calf serum showed greater multiplication and had a longer logarithmic growth phase, the stationary growth phase not being reached until the 12 th day. The analysis of variance showed that the differences between the effects of the various insulin concentrations $(0-10000 \mathrm{mU} / \mathrm{l})$ were significant $(\mathrm{p}<0.001)$. There was also a significance between the mean cell counts in each treatment group and the corresponding hormone concentration $(\mathrm{p}<0.001)$. The F-test showed that the differences of the mean cell counts on days 4,6 and 8 were significant $(p<0.001)$.

In separate studies the effect of insulin on the proliferation of smooth muscle cells in the stationary growth phase was studied in medium containing $10 \mathrm{ml} / 1$ serum (Fig. 3). From day 0, the day when cells had achieved stationary growth, the basal 

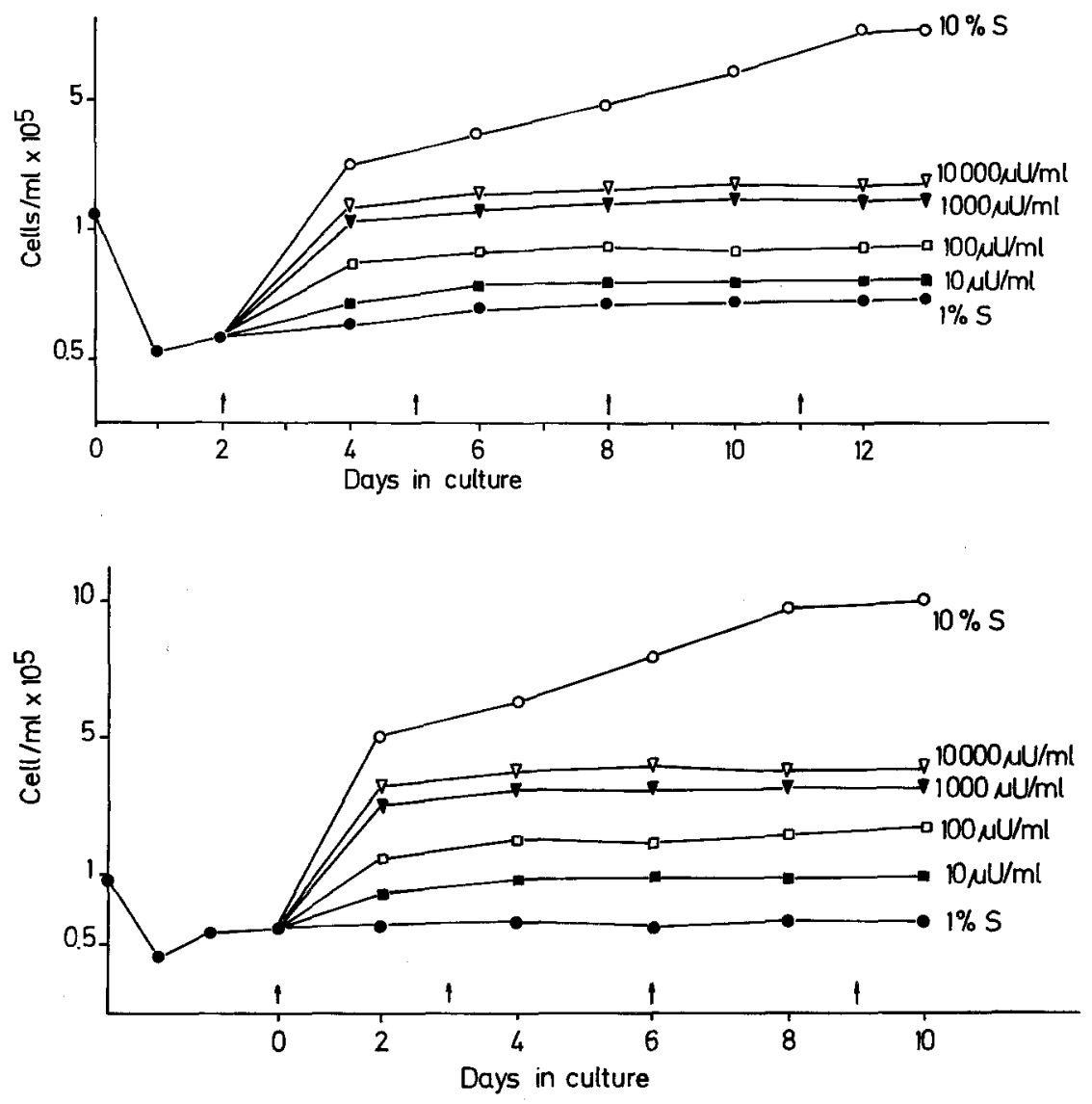

Fig. 2. The effect of insulin on the proliferation of cultured human arterial smooth muscle cells in the logarithmic growth phase. The cells used in this study were from the 4th passage. Insulin was tested at a concentration of $10-10000 \mathrm{mU} / 1$ in comparison with culture medium containing $10 \mathrm{ml} / 1 \mathrm{fetal}$ calf serum $(1 \% \mathrm{~S})$ or $100 \mathrm{ml} / 1$ fetal calf serum $(10 \% \mathrm{~S})$. Each point is the mean cell count of twofold determination in two replicate plates. The change to fresh medium is indicated by arrows
Fig. 3. The effect of insulin on the proliferation of cultured human arterial smooth muscle cells in the stationary growth phase. The cells used in this study were from the 5 th passage. Insulin was tested at a concentration of 10-10000 $\mathrm{mU} / \mathrm{l}$ in comparison with culture medium containing 10 or $100 \mathrm{ml} / 1$ fetal calf serum $(1 \% \mathrm{~S}, 10 \% \mathrm{~S})$. Each point is the mean cell count of twofold determination in two replicate plates medium was removed and the test medium was added. In this experiment, insulin significantly stimulated cell proliferation at all concentrations ( $p$ $<0.001)$. Proliferation was most increased in the first $2 \mathrm{~d}$ after the test medium was added. On day 4 the stationary growth phase was again achieved. Medium containing $100 \mathrm{ml} / 1$ serum stimulated cell proliferation more. Stationary growth was achieved on day 9 . For this experiment the same statistical analysis was performed as described above, all tests being significant $(\mathrm{p}<0.001)$.

\section{Discussion}

The foregoing studies show that the proliferation of human arterial smooth muscle cells was stimulated even by small concentrations of insulin similar to those found in plasma under physiological conditions. Our previous studies [4] with cultivated arterial smooth muscle cells of rats showed that the growth of these cells can also be stimulated by a medium containing insulin. Stout et al. [5] demonstrated that insulin at a concentration of $10-10000 \mathrm{mU} / 1$ stimulated the proliferation of arterial smooth muscle cells of monkeys (Macaca nemistrina). All these studies suggest strongly that insulin is a growth-factor of serum, able to stimulate the proliferation of smooth muscle cells of vessel wall.

Atherosclerosis is the principal cause of death among diabetic patients. A study in the Joslin Clinic in Boston between 1956-1968 [7] showed that about $78 \%$ of diabetic patients die from cardiovascularrenal disease. Cardiac death alone accounted for more than half of all deaths. In Finland a five-year prospective study of risk factors for coronary heart disease was carried out $[8,9]$. The study showed that men with high plasma insulin levels had a two to threefold increase in coronary heart disease. The effect of insulin was independent of other risk factors. Our laboratory studies show that insulin in physiological concentrations stimulated the proliferation of cultured human arterial smooth muscle cells. From the clinical observations in Helsinki and from our in vitro experiments we conclude that insulin itself could have a direct effect on the pathogenesis of atherosclerosis.

In contrast to our results, Ledet [10] found that the addition of insulin in various concentrations $(2,5$ and $100 \mathrm{mU} / \mathrm{l}$ ) to nondiabetic human serum did not 
result in enhancement of the growth of the cultured rabbit arterial smooth muscle cell. It is possible that he could not observe an effect of insulin at these low concentrations with the high serum concentration $(50 \mathrm{ml} / \mathrm{l})$ used in his experiments.

The mechanism of action of insulin on arterial smooth muscle cells is unknown. Steiner et al. [11] described insulin as a cellular growth ragulator of hepatocytes and discussed a new hypothesis regarding the role of the insulin-receptor-complex in initiating the metabolic and mitogenic effects of insulin. Many questions about the mechanism of the regulation of cell proliferation by insulin remain to be studied, however.

Acknowledgements. The electronmicroscopic study was carried out in the section of electronmicroscopy (Prof. Dr. R. Martin). We wish to thank all collaborators of the section for their helpful assistance. We also wish to thank Mrs. Doris Kulka for technical assistance.

\section{References}

1. Meissner WA, Legg MA (1973) The pathology of diabetes. In: Marble A, White P, Bradley RF, Krall LP (eds) Joslin's diabetes mellitus. Lea \& Febiger, Philadelphia, p 157-190

2. Ross R, Glomset $\mathfrak{J}$ (1973) Atherosclerosis and the arterial smooth muscle cell. Science 180: 1332-1339

3. Ross R, Glomset J, Harker L (1977) Response to injury and atherogenesis. Am J Pathol 86: 675-684
4. Pfeifle B, Ditschuneit HH, Ditschuneit $H$ (1980) Insulin as a cellular growth regulator of rat arterial smooth muscle cells in vitro. Horm Metab Res 12: 381-385

5. Stout RW, Bierman L, Ross R (1975) Effect of insulin on the proliferation of cultured primate arterial smooth muscle cells. Circ Res 36: 319-327

6. Stout RW (1979) Diabetes and atherosclerosis - The role of insulin. Diabetologia 16: 141-150

7. Krall LP (1973) Clinical evaluation of prognosis. In: Marble A, White P, Bradley RF, Krall LP (eds) Joslin's diabetes mellitus. Lea \& Febiger, Philadelphia, p 211-254

8. Pyörälä K (1979) High plasma insulin level a prime risk factor for heart disease. JAMA 241: 1665

9. Pyörälä K (1979) Relationship of glucose tolerance and plasma insulin to the incidence of coronary heart disease: results from two populations studies in Finland. Diabetes Care 2: $131-141$

10. Ledet $T$ (1976) Growth hormone stimulating the growth of arterial medial cells in vitro. Diabetes 25: 1011-17

11. Steiner DF, Chan SJ, Terris S, Hofmann C (1978) Insulin as a cellular growth regulator. In: Porter $\mathbf{R}$, Whelan $\mathbf{J}$ (eds) Hepatotrophic factors. Ciba Found Symp 1977. Elsevier, Amsterdam, 55: 217-228

Received: May 12, 1980,

and in revised form: October 6,1980

Dr. Beate Pfeifle

Department of Internal Medicine

University of Ulm

Steinhövelstraße 9

D-7900 UIm/Donau

Federal Republic of Germany 